\title{
Genetic Divergence Analysis in Fennel Genotypes
}

\author{
Lad Dhakar ${ }^{1}$, R.S. Meena ${ }^{2}$, Seema Jat ${ }^{3 *}$ and Tarachand Yadav ${ }^{1}$ \\ ${ }^{1}$ Mahatma Jyoti Rao Poole University, Jaipur, India \\ ${ }^{2}$ ICAR-National Research Centre on Seed Spices, Ajmer, India \\ ${ }^{3}$ Dayanand College, Ajmer, India \\ *Corresponding author
}

\section{Keywords \\ $\mathrm{D}^{2}$ statistics, \\ Genetic divergence, \\ Foeniculum \\ vulgare, Cluster}

Article Info

Accepted:

04 June 2018

Available Online:

10 July 2018

\section{A B S T R A C T}

An experiment was conducted to study a genetic divergence analysis were estimated in 19 genotypes of fennel (Foeniculum vulgareMill.) grown in a Randomized Block Design (RBD) with three replications during Rabi season of 2016-17 at the research farm of ICAR-National Research Centre on Seed Spices, Tabiji, Ajmer (Rajasthan). Mahalanobia $\mathrm{D}^{2}$ statistic indicated wider genetic diversity in the population. All genotypes were grouped into seven clusters on the basis of diversity. Estimates of intracluster distance ranged from 0.00-5.70. The maximum intra cluster distance was observed within cluster I $(\mathrm{D}=5.70)$, whereas, III, IV, V, VI and VII showed the minimum intra cluster distance $(\mathrm{D}=0.00)$ followed by cluster II $(\mathrm{D}=4.91)$. It was maximum in cluster I and minimum in cluster III, IV, V, VI and VII. Tocher's method of hierarchical cluster analysis was applied to group the varieties. The maximum inter-cluster distance between cluster V and IV was 6.51 and 14.58, respectively. The genotypes falling in cluster II were GF-11, RF-157, RAJENDRA SAURBH, RF-205, AZAD SAUNF-1, CO-1, RF-101 and GF-12, in cluster I RF-178, RF-281, GF-2, RF-143, RF-145 and RF-125, in cluster III AF-2, in cluster IV GF1 , in cluster $\mathrm{V} A F-1$, in cluster VI one HISAR SWARUP, incluster VIIPANT MADURIKA. Clusters I and II showed the highest genetic distance between them. Cluster means showed that, the cluster I showed the highest mean values for plant height (150.83) and the lowest mean value for seed yield per plot (1.08). Among the 13 characters studied for genetic divergence, seed yield per plot $(\mathrm{kg})$ contributed the maximum accounting for $49.12 \%$ of total divergence, followed by number of umbles per plant 29.82 .

\section{Introduction}

Fennel (Foeniculum vulgare Mill.), belongs to family Apiaceae. It is a diploid species with chromosome number, $2 \mathrm{n}=22$ and native of Europe and Mediterranean region (Agarwal et al., 2001). Seed spices include all those annuals whose dried fruits or seed are used as spices and condiment viz., fennel, fenugreek, coriander, cumin, aniseed, ajwain, dill, nigella and celery etc. Among them fennel is a major seed spice crop, which is used in seed spice and culinary purposes. These seed spices play an important role in national economy. In India, Rajasthan and Gujarat are known as "seed spices bowl" and contributes more than 
$80 \%$ of total seed spices production. The other states where seed spices are commonly grown are Bihar, West Bengal, Uttar Pradesh, Madhya Pradesh, Orissa, Punjab, Karnataka and Tamil Nadu. Out of 31.92 lakh ha area and 61.69 lakh tonnes production of total spices presently 16.53 lakh ha of area is under seed spices cultivation with a production of 11.75 lakh tonnes annually. The seed spices contribute $10-12 \%$ of total export of spices and account for about $51.79 \%$ and $19.06 \%$ of total area and production, respectively of total spices in the country. The export of seed spices in 2015-16 was 216870 tonnes valued Rs 2617.15 crores and its global demand is increasing day by day. Indian spices and spice products are exported to more than 135 countries and leading among them are USA, Malaysia, UAE, China and UK.

The development of new varieties or improvement in any crop mainly governed by the magnitude of genetic diversity and the extent of available variability for the desired characters. The nature and magnitude of genetic divergence in a population is essential for selecting diverse parents which upon hybridization leads to greater opportunity for crossing over which release latest variation by breaking up the predominantly repulsion phase linkages. The use of D2 statistics of multivariate analysis gives an understanding of genetic diversity in the fennel. D2 measures the degree of diversity and determines the relative proportion of each component traits to the total divergence.

\section{Materials and Methods}

The experiment was laid out at research farm of ICAR-National Research Centre on Seed Spices, Ajmer, Rajasthan, during rabi season of 2016-17. The centre lies on $74^{0} 35^{\prime} 39^{\prime \prime}$ E to $74^{0} 36^{\prime} 01^{\prime \prime}$ longitude and $26^{\circ} 22^{\prime} 12^{\prime \prime}$ to $26^{0}$ 22 ' 31" N latitude at an altitude of $460.17 \mathrm{~m}$ above mean sea level, in Ajmer district of
Rajasthan. The region falls under agro climatic zone III of Rajasthan. The soil of research farm is sandy loam, poor in fertility and water holding capacity, having $\mathrm{pH}$ 8 to 8.3 , EC 0.07 to 0.12 and organic carbon 0.15 to $0.23 \%$, available $\mathrm{N} 178.5 \mathrm{~kg} \mathrm{ha}^{-1}$ (low), $\mathrm{P}_{2} \mathrm{O}_{5} 12 \mathrm{~kg} \mathrm{ha}^{-1}$ (medium), $\mathrm{K}_{2} \mathrm{O} 85 \mathrm{~kg}$ $\mathrm{ha}^{-1}$ (low), Ca $214.7 \mathrm{~kg} \mathrm{ha}^{-1}$ (high), $\mathrm{Mg} 258 \mathrm{~kg}$ $\mathrm{ha}^{-1}$ (medium), S $27 \mathrm{~kg} \mathrm{ha}^{-1}$ (medium).The maximum and minimum temperature during growing season of fennel (October to April) recorded was $32.22^{\circ}$ and $6.72^{\circ} \mathrm{C}$, respectively. Total rainfall of study period was $26.37 \mathrm{~mm}$. The study was carried out with 19 released varieties in India of fennel namely, GF-11, RF-157, RAJENDRA SAURBH, RF-205, AZAD SAUNF-1, CO-1, RF-101, GF-12, RF178, RF-281, GF-2, RF-143, RF-145, RF-125, AF-2, GF-1, AF-1, HISAR SWARUP, and PANT MADURIKA. These varieties were developed by different research institutes situated at different agro-ecological conditions, thus have different genetical backgrounds. The experiment was laid out in randomized block design with three replications. Plot size $3 \times 2 \mathrm{~m}$ and Spacing $(\mathrm{R} \times \mathrm{P}) 50 \times 25 \mathrm{~cm}$. The recommended package of practices was adopted for raising healthy crop. Five plants were randomly selected from each plot and observations were recorded on days to germination, duration of king umbel anthesis, days to $50 \%$ flowering, number of primary branches per plant, number of secondary branches per plant, plant height $(\mathrm{cm})$, diameter of king umbel $(\mathrm{cm})$, numbers of umbels per plant, numbers of umbellets per umbel, number of seeds per umbellet, test weight $(\mathrm{gm})$, seed yield per plot $(\mathrm{kg})$ and essential oil (\%). Data was pooled and genetic divergence was analysed through Winstat version 8.5. The genetic divergence was estimated using theMahalanobis D2, Mahanalobis and the varieties were grouped into clusters by following the Tocher's method described by Rao (1952). 


\section{Results and Discussion}

The genetic diversity existing in the population helps in selecting suitable parents for the hybridization programme. Mahalanobis's $\mathrm{D}^{2}$ statistic is employed to assess the amount of genetic diversity and a rational choice of potential parents for hybridization in breeding programme. Average linkage tends to eleven clusters with small variance and is slightly biased towards producing clusters with the some variance (Johnson and Wichern, 1996).

The results on genetic divergence are presented below. Based upon observations of thirteen characters the Mahalanobis's statistic were computed for 19 genotypes.

Based on $\mathrm{D}^{2}$ value, the 19 genotype could be grouped in to seven clusters. The cluster pattern of these genotypes is depicted in Table 1.cluster II was the largest comprising of 8 genotypes.

The second largest cluster was cluster I containing 6 genotypes and followed by cluster III, cluster IV, cluster V, cluster VI and cluster VII with $1,1,1,1$ and 1 genotypes respectively. Genetic drift and selection forces under diverse environments could cause greater diversity than geographical distance Kole et al., (2013). Genotype from different geographical regions were also grouped in the same cluster indicating no relationship between geographical distribution and genetic divergence, similar results were also reported by Meena et al., (2010) and Meena et al., (2014)

A personal of results on intra cluster and inter cluster distance (Table 2) revealed very interesting trend of genetic diversity. Intracluster $\left(\mathrm{D}^{2}\right)$ values of various clusters were found to be relatively high indicating thereby the presence of substantial genetic diversity even within a cluster. The minimum inter cluster distance (6.51) was observed between clusters I and II followed by clusters V and VI (7.13). Shalini et al., (2000) and Verma and Sachan (2000) also reported considerable diversity in Indian mustard and Meena et al., (2010) are reported in fennel. In heterosis breeding, genotypes of diverse clusters are likely to play an important role as potential parents as when genotypes from different clusters are intercrossed they are likely to produce heterotic combinations.

Table.1 Distribution of 19 fennel varieties in clusters based on $\mathrm{D}^{2}$ values

\begin{tabular}{|l|c|l|}
\hline Cluster No & $\begin{array}{l}\text { Number of } \\
\text { genotypes }\end{array}$ & Name of the genotypes \\
\hline Cluster I & 6 & RF-178, RF-281, GF-2, RF-143, RF-145, RF-125 \\
\hline Cluster II & 8 & $\begin{array}{l}\text { GF-11, RF-157, RAJENDRA SAURBH, RF-205,AZAD } \\
\text { SAUNF-1, CO-1, RF-101, GF-12 }\end{array}$ \\
\hline Cluster III & 1 & AF-2 \\
\hline Cluster IV & 1 & GF-1 \\
\hline Cluster V & 1 & AF-1 \\
\hline Cluster VI & 1 & HISAR SWARUP \\
\hline Cluster VII & 1 & PANT MADURIKA \\
\hline
\end{tabular}


Int.J.Curr.Microbiol.App.Sci (2018) 7(7): 403-408

Table.2 Intra (bold) and Inter cluster distance assessed in fennel genotypes

\begin{tabular}{|l|r|r|r|r|r|r|r|}
\hline Clusters & Cluster 1 & Cluster 2 & Cluster 3 & Cluster 4 & Cluster 5 & Cluster 6 & Cluster 7 \\
\hline Cluster 1 & $\mathbf{5 . 7 0}$ & 7.82 & 7.56 & 7.96 & 8.64 & 8.00 & 11.24 \\
\hline Cluster 2 & & $\mathbf{4 . 9 1}$ & 7.69 & 9.93 & 10.48 & 12.30 & 9.30 \\
\hline Cluster 3 & & & $\mathbf{0 . 0 0}$ & 7.84 & 12.98 & 11.17 & 13.46 \\
\hline Cluster 4 & & & & $\mathbf{0 . 0 0}$ & 12.75 & 10.79 & 14.58 \\
\hline Cluster 5 & & & & $\mathbf{0 . 0 0}$ & 7.13 & 6.51 \\
\hline Cluster 6 & & & & & & $\mathbf{0 . 0 0}$ & 11.94 \\
\hline Cluster 7 & & & & & & & $\mathbf{0 . 0 0}$ \\
\hline
\end{tabular}

Table.3 Contribution of various characters to divergence in fennel

\begin{tabular}{|l|l|l|l|}
\hline S.NO. & Characters & Time Ranked $1^{\text {st }}$ & Contribution $\%$ \\
\hline 1. & Days to germination & 6 & $3.51 \%$ \\
\hline 2. & King umbel anthesis & 2 & $1.17 \%$ \\
\hline 3. & $50 \%$ flowering & 2 & $1.17 \%$ \\
\hline 4. & King umbel diameter $(\mathrm{cm})$ & 0 & $0.00 \%$ \\
\hline 5. & Plant height $(\mathrm{cm})$ & 2 & $1.17 \%$ \\
\hline 6. & Number of primary branches & 5 & $2.92 \%$ \\
\hline 7. & Number of secondary branches & 7 & $4.09 \%$ \\
\hline 8. & Number of umbels per plant & 51 & $29.82 \%$ \\
\hline 9. & Number ofumbellets per umbel & 3 & $1.75 \%$ \\
\hline 10. & Number of Seeds per umbellets & 0 & $0.00 \%$ \\
\hline 11. & Test weight $(\mathrm{g})$ & 3 & $1.75 \%$ \\
\hline 12. & Seed yield per plot $(\mathrm{kg})$ & 84 & $49.12 \%$ \\
\hline 13. & Essential oil $\%$ & 6 & $3.51 \%$ \\
\hline & & & \\
\hline
\end{tabular}

Table.4 Cluster means for various characters in fennel genotypes

\begin{tabular}{|c|c|c|c|c|c|c|c|c|c|c|c|c|c|c|}
\hline 莺 & 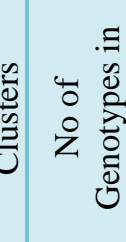 & 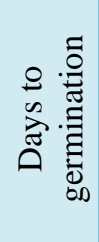 & 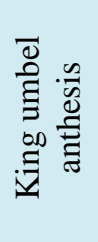 & 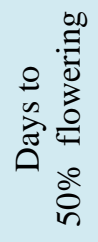 & 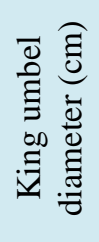 & 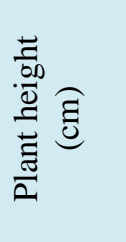 & 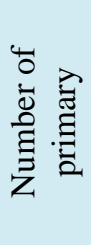 & 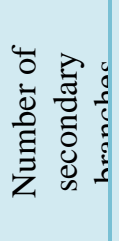 & 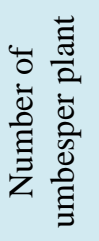 & 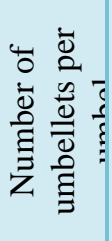 & 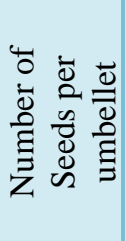 & 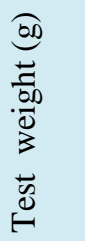 & 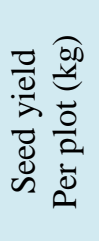 & 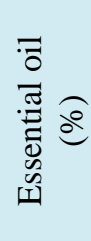 \\
\hline Cluster 1 & 6 & 8.17 & 25.44 & 84.33 & 14.66 & 150.83 & 9.01 & 28.20 & 47.13 & 21.20 & 24.68 & 7.19 & 1.08 & 2.00 \\
\hline Cluster 2 & 8 & 8.25 & 25.44 & 84.46 & 15.34 & 149.19 & 7.97 & 26.10 & 48.94 & 23.66 & 25.35 & 7.17 & 1.45 & 2.08 \\
\hline Cluster 3 & 1 & 7.33 & 27.67 & 93.00 & 16.93 & 153.67 & 8.20 & 28.07 & 37.30 & 23.60 & 27.87 & 6.65 & 1.29 & 2.22 \\
\hline Cluster 4 & 1 & 7.00 & 24.67 & 76.67 & 15.13 & 138.00 & 6.19 & 12.13 & 32.33 & 21.93 & 25.07 & 6.46 & 0.86 & 1.83 \\
\hline Cluster 5 & 1 & 7.33 & 24.67 & 93.00 & 15.73 & 167.33 & 9.07 & 28.33 & 74.33 & 23.00 & 28.93 & 7.17 & 0.90 & 1.77 \\
\hline Cluster 6 & 1 & 8.67 & 25.00 & 99.00 & 16.47 & 165.00 & 9.33 & 29.00 & 57.00 & 26.47 & 26.60 & 6.98 & 0.70 & 2.16 \\
\hline Cluster 7 & 1 & 7.00 & 24.67 & 96.00 & 18.93 & 165.00 & 8.20 & 24.33 & 81.00 & 26.67 & 30.73 & 6.92 & 1.28 & 1.94 \\
\hline
\end{tabular}




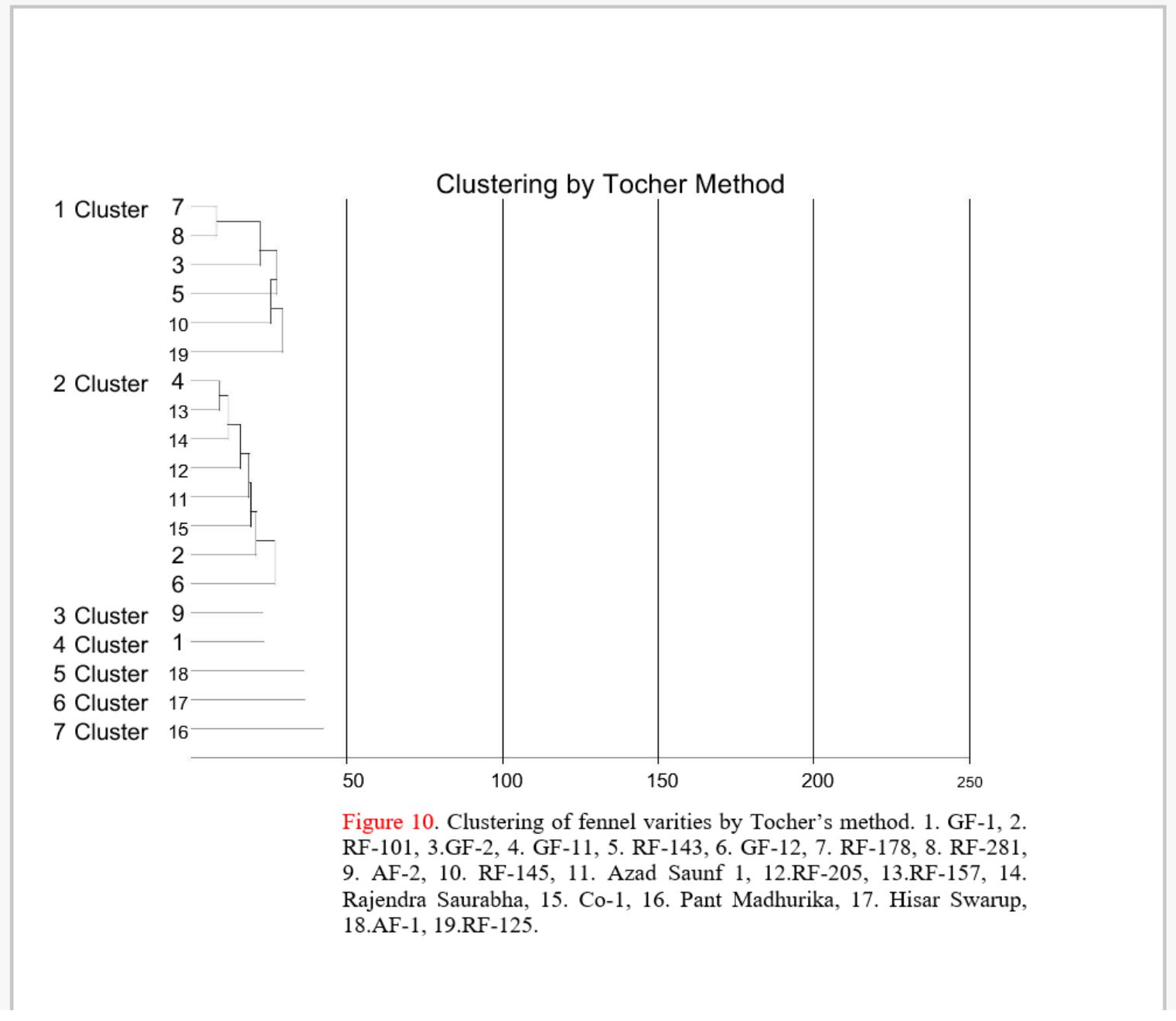

The contribution of individual characters to the divergence was worked out in terms of number of times it appeared first (Table 3) seed yield per plot (1.08) contributed maximum towards genetic divergence, followed by number of umbels per plant, number of secondary branches, days to germination and essential oil. Selection of parents from diverse clusters in breeding programmes has been suggested by many workers in pulse crop Kumar et al., (1998) for exploiting non-additive gene action.

In the present study (Table 4), revealed that cluster I showed the highest mean value for plant height (150.83), days to $50 \%$ flowering (84.33), number of umbels per plant (47.13), number of seeds per umbellet (24.68), number of umbellets per umbel (21.20), number of primary branches (9.01), test weight (7.19) and the lowest mean value for seed yield per plot (1.08). Cluster VI had the smallest mean value for seed yield per plot (0.70), essential oil (2.16), test weight (6.98), number of primary branches (9.33), number of seeds per umbellet (26.60), number of umbellets per umbel (26.47), number of secondary branches (29.00), number of umbels per plant (57.00) and plant height (165).

The clustering pattern could be utilized in choosing the parents or making cross combinations which may generate high variability for various traits. Selection based on cluster means and inter cluster distances may be effective. 
These studies indicated the geographic and genetic diversity are not necessarily related. Therefore, the selection of varieties for hybridization should be based on genetic diversity rather than geographic diversity. Similar results were also reported by Agnihotri et al., (1990) and Meena et al., (2017) in fennel. Hence, it is suggested that inter-mating between the genotypes included in these diverse clusters may give high heterotic response and thus better segregants. This will provide an opportunity to select better recombinants for various characters and thereby creating large variability for these characters in the inter-clusters distances.

\section{References}

Agarwal, A.K., Hatfield, J., Kemery, E., Valenti, S. and Esnault, L. 2001. Webbased education: changing the equilibrium in managing information technology in a global economy. Proceedings of the IRMA International Conference, May 20-23, 2001, Idea Group Publishing: Hershey London Melbourne Singapore, Toronto, p: 1197.

Agnihotri, P. 1990. Genetic divergence in the germplasm of fennel. M.Sc. (Ag.); Thesis, Rajasthan Agricultural University, Bikaner, Campus-Jobner (Rajasthan).

Johnson, R.A. and Wichern, D.W. 1996. Applied multivariate statistical analysis. Prentice-Hall of India Private Limited.

Kole, P.C., Saha, A. and Hasib, K.M. 2003.
$\mathrm{D}^{2}$ analysis in fenugreek (Trigonella foenum-graecum L.). Crop Research Hisar. 26(2): 339-342.

Kumar, A., Krishna, R. and Chaturvedi, S.K. 1998.Genetic divergence in chickpea (Cicer arietinum L.). Indian J. Genet. 58: 337-42.

Mahalonobis, P.C. 1936. On the generalized distance in statistics. Production. Nath. Inst. Science. India. 2:49-50.

Meena, R.S., Kakani, R.K., Choudhary, S., Singh, B. and Panwar, A. 2014. Genetic diversity analysis in coriander (Coriandrum sativum L.) varieties. Indian Journal of Agricultural Sciences. 84(12): 1508-12,

Meena, R.S., Anwer, M.M., Lal, G., Mehta, R.S., Kakani, R.K. and Panwar, A. 2010. Genetic diversity analysis in fennel. Indian Journal of Horticulture. 67(4): 500-504.

Meena, R.S., Solanki, R.K., Kakani, R.K., Singh, B. and Panwar, A. 2017. Genetic divergence among genotypes of cumin (Cuminum cyminum). Indian journal of Agriculture Science. 87(4):459-61

Rao, C.R. 1952. Advanced Statistical Methods in Biometrical Research. John Wiley \& Sons Inc., New York.

Shalini, T.S., Sheriff, R.A., Kulkarni, R.S. and Venkataravana, P. 2000. Genetic divergence in Indian mustard (Brassica juncea L.) Czern\&Coss). Mysore Journal of agriculture Science.34: 251-256.

Spice Board, 2015-16. www.indianspice.com.

\section{How to cite this article:}

Lad Dhakar, R.S. Meena, Seema Jat and Tarachand Yadav. 2018. Genetic Divergence Analysis in Fennel Genotypes. Int.J.Curr.Microbiol.App.Sci. 7(07): 403-408. doi: https://doi.org/10.20546/ijcmas.2018.707.049 